\title{
Economic Uncertainty And The Role Of Organizational Development
}

\author{
Martin D. Carrigan, University of Findlay, USA
}

\begin{abstract}
The US Economy has entered an era of economic uncertainty. Stock markets are down. Unemployment is up. This paper examines the effect of economic uncertainty on organizational behavior.
\end{abstract}

Keywords: economic uncertainty; organizational development; motivation; strategies; Drucker; Hawthorne studies; May; Maslow; Herzberg; engagement; satisfaction; rewards; hierarchy of needs; incentives; monetary incentives; Walton; Wal-Mart; organizational climate

\section{INTRODUCTION}

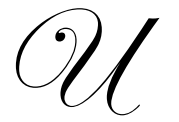

SA businesses presently experience a work force lacking motivation except to preserve their own job, falling productivity, and individual concerns about their own future. With economic statistics demonstrating high unemployment, continuing employment claims, negative national output and low consumer confidence, new problems arise for many companies across the nation. Even now, some economists believe that the current situation is bound to get worse before it gets better. Peter Drucker once said "The greatest danger in times of turbulence is not the turbulence, it is to act with yesterday's logic." Therefore, organizations must now learn to be flexible and proactive. While companies are rethinking their strategies for the future, many are wondering where to begin in such an unpredictable time and are asking the question, "What are the best strategies to use for reconstruction during this financial crisis?"

Lay-offs, cutbacks, and foreclosures have been sweeping businesses across the country. The recession has indeed taken its toll, as anxieties are high and employees are growing more and more disheartened. Fear, doubt, and frustration are widespread. Thus, the economic uncertainty has had an immense influence on employee motivation, retention, and productivity. But is it possible to motivate employees to such a degree that they overcome such obstacles? Certainly, managers have a critical role to play in these tough times. Some leaders have put up a façade and seem unaffected while with others, their actions show that they are greatly distressed. However, the actions they take can help in improving employee drive and enthusiasm. The strategies put into place now will later affect morale once the unstable market turns around. Hence, management teams must begin analyzing their approach. Now the question remains: What aspects of motivation are key for developing solutions?

While the current economic situation may seem hopeless at times, there are still opportunities present from which businesses can thrive. When organizations adopt this optimistic mindset, they set themselves up for success. Having a clear vision alone can nurture organizational commitment and dedication. However, many other aspects go into account when striving to set a motivational culture. Therefore, having an understanding of the basic principles for motivation is important, especially in unfavorable environments.

\section{BASIC PRINCIPLES OF MOTIVATION}

The Hawthorne studies, conducted between 1924 and 1927, may mark the modern analyses of human relations. Done at the Hawthorne plant of an AT\&T subsidiary, the company's engineers were looking to explore issues regarding productivity. When the engineers had changed the lighting, performance was enhanced. As illumination increased, so did productivity. Surprisingly, when lighting was set low, productivity also improved. Because the employees enjoyed the extra attention from management, they reacted positively (Dubrin, 2008). 
From these results, further studies were conducted by Harvard professors involving intrinsic and extrinsic motivational factors. Research showed that economic incentives were not as important in employee efficiency as were such methods involving leadership practices, like coaching, and work-group pressures. Not only did these approaches increase performance, but they also boosted satisfaction. In brief, understanding the social setting of the work environment is an important aspect in altering behavior (Dubrin, 2008).

The findings of the Hawthorne studies and of those that followed established the basis for human relations management. Up until this time, it was believed that that the most effective workers were driven by their pay. These studies posed the revolutionary idea for organizations to adopt: successful workers are motivated by social needs, such as developing work relations and facing pressures put forth by coworkers. Employees also push themselves to succeed when they are recognized by their managers. Though salary is still an important factor, it is with a combination of responsibility, respect, and recognition that fully increase its contribution to motivation in the workplace.

Nonetheless, ever since Elton May altered the lights in the famous Hawthorne experiments people have struggled to understand workplace motivation. Frederick Herzberg (1987) states in his Harvard Business Review article, "One more time: How do you motivate employees?", "What has been unraveled [about the psychology of motivation] with any degree of assurance is small indeed" (p. 86). Because it is so central to organizational success, new research continues that gives further insight into how the human brain operates. In research conducted by Nitin Nohria, Boris Groysberg, and Linda-Eling Lee (2008), it suggests that people are guided by four basic emotional needs. They are the drives to acquire, bond, comprehend, and defend. These four concepts are thought to underlie all human behavior.

In later studies that measured the presence of the four emotional needs and their effects on engagement, satisfaction, commitment, and intention to quit, the results were striking. In short, an organization's ability to meet fundamental drives explains, on average, about $60 \%$ of employees' variance on motivational indicators (Nohria, Groysberg, \& Lee, 2008). Consequently, applying all four drives in unison proves for the most favorable results. Furthermore, these drives can each be applied by a motivational lever.

The first, rewards systems, relate clearly to performance and fulfill the drive to acquire. Next, culture, or one that promotes teamwork, collaboration, and openness, allows for bonding. The need to comprehend is satisfied by job designs that are meaningful and challenging. Finally, fair and clear processes for performance management and resource allocation meet the drive to defend. In addition to the four emotional drives, the role of the direct manager's application of these also played an important part in motivation.

Moreover, understanding human needs can help in relating to motivating workers. Abraham Maslow's Hierarchy of Needs focuses on this subject, and suggests that there are five levels of needs to be satisfied in progression. As one need is satisfied, reaching the next one becomes the driving force. At the first level, physiological needs for water, food and comfort exist. Next, the focus turns to safety and security, enabling a person to settle. After, social needs come into play, in which a person looks for friendships among those with similar values. At the fourth level, a desire for self-respect and recognition become apparent and a person seeks to be unique. Finally, the last stage brings self-actualization. It is an ongoing process driven by potential and purpose (Dubrin, 2008).

Considering Maslow's Hierarchy of needs from an organizational perspective, Level I relates to the work environment or salary. The next includes such things as health insurance or bonuses. If these factors are absent, people may seek a more secure workplace. Level III includes socialization opportunities within the job while the next drives personal success. The final step gives a deeper purpose to a career.

In studying another model, Frederick Herzberg put forth the two-factor theory of work motivation. One set of job factors, motivators or satisfiers, simply as they say, can motivate and satisfy workers. They include achievement, recognition, the work itself, responsibility, and growth and are intrinsic to the job. Dissatisfiers, or hygiene factors, prevent dissatisfaction, are extrinsic to the job, and include company policy, supervision, relationships, working conditions, salary, and security. Hygiene factors relate to the first three levels of Maslow's Hierarchy, while motivators are relative to levels four and five. 
Herzberg believed that organizations must have functional incentive systems in order to effectively motivate employees. To clarify, Herzberg (1987) states:

"If I kick my dog, he will move. And when I want him to move again, what must I do? I must kick him again. Similarly, I can charge a person's battery, and then recharge it, and recharge it again. But it is only when one has a generator of one's own that we can talk about motivation. One then needs no outside stimulation. One wants to do $i t^{\prime \prime}$ (p. 88).

Though unfair salaries may de-motivate people, large salaries do not motivate them either. Only interesting, challenging work and increased responsibility can do that. Therefore, according to his theory, the concentration should be on enriching the work.

\section{MOTIVATION DURING ECONOMIC INSTABILITY}

Organizational decline is a frequent occurrence in an economic crisis. Unfortunately with it comes job insecurity. According to Leonard Greenhalgh (1983), the decline takes place when organizations produce goods and services most of its customers no longer want. Shrinkage, which usually involves reducing the workforce, then occurs to cope with the decline. This then creates job insecurity among members of the organization. Job insecurity is defined as "feeling powerless to maintain desired continuity in a work situation" (Greenhalgh, 1983, p. 432). It involves the fear of losing the job, along with the features that come along with it, such as status, contact with coworkers, or privileges. Nonetheless, the greater the job insecurity, the greater are employees' adverse reactions.

Other main concerns include protection and the fairness of the company's procedure for workforce reductions. Much of the reason that these uncertainties arise is due to the lack of communication or withholding of information from employees. Though many managers believe discretion is best during an economic crisis, due to the fact that announcing cuts could cause demoralization and disorder, it often times makes already difficult situations worse. Employees instead rely on the inaccurate source of rumors. Consequences such a change in attitudes and lower productivity are likely to transpire. People have difficulty concentrating, become forgetful, show anger, and absenteeism becomes more likely. These high anxiety levels result in diminished work efforts and commitment to the organization (Greenhalgh, 1983).

Getting people to perform their best, especially in trying circumstances, can be tedious for managers. According to Barnett Helzberg, Jr. (2003), the former chairman of Helzberg Diamonds, in the article "Motivating your sales force in a tough economy," one of the worst techniques management can apply is bearing down on their sales force with threats to produce. Tough times, instead, are the instances when supervisors should strive to trust lower-level employees. Though many people develop a mindset for buckling down amidst the emotions, implementing too many trivial rules will only makes employees uneasy, which usually accounts for more mistakes. Alternatively, Helzberg (2003) in his business, set expectations high, gave frequent feedback, and celebrated successes. With a more comfortable atmosphere set, sales greatly increased.

From this success, Helzberg (2003) noted that personal inspiration for management followed. It was also suggested that macro-managing rather than micro-managing is important for organizational development. Employees then are given more responsibility, a sense of ownership and the chance to grow. However, Helzberg (2003) does suggest recognizing the ability for motivation before progressing forth. "You can win with winners," he states, "even in a tough economy" (Helzberg, 2003, p. 13). From there, he discusses the success of aiding in setting goals, but allowing for freedom to apply individual ideas. Finally, when management discovers what kind of recognition reinforces positive behaviors, it should be implemented accordingly. He says, "In business, sincere use of positive reinforcement has proven effective time after time. A basic need of every human being is to feel appreciated."

In order for managers to inspire employees during economic uncertainty, managers, too, must be optimistic and motivated. Sam Walton, the founder of Wal-Mart, which finished atop Fortune's 500 list in 2008, applied certain strategies over the years for motivating his management teams (Motivating, 2003). "He believed that managers get more from their staff when they treat them as associates or partners, not employees" (Motivating, 
2003, p.14). In addition, he urged managers to encourage their staff support each other. Walton also mentions motivating factors such as communicating everything possible to teams, listening to what they have to say back, openly appreciating one another, and holding each other accountable for work tasks.

Monetary incentives, as discussed in theory, are only effective if workers are motivated by money only, lasting only as long as they have a need for it. Once satisfied, the drive will no longer exist as a motivating force. Therefore, motivation must take place on a different basis. People, instead, enjoy things that are meaningful to them. The key then is to try to make work teams feel as if they are contributing to something valuable.

In bringing Maslow and Herzberg's theories into the workplace, strategies for motivation can be implemented to in order to meet people basic needs. Once each is met, difficult and challenging times can actually motivate workers to contribute at a higher level. Naturally, fundamentals like salary, breaks and favorable work conditions must be in place. In order to gain organizational loyalty, bonuses and healthcare plans can be motivating. Other factors include giving employees the opportunity to grow. This can occur through training and coaching, and relates to findings in the Hawthorne studies for driving efforts as well.

Next companies should consider how well defined work roles are within their organization. If teams are established, do they have a sense of identity? Evaluating communication is also necessary. Means for two-way communication must be set in place. It is important for management to pass along information, and just as important to provide opportunities for feedback from employees. Workers should also have the chance to be creative with their work, as doing so allows them to contribute, gives them ownership and builds loyalty. These achievements should then be noticeably recognized by superiors. Inspiring leaders are aware of the importance in pointing out moments of achievement with praise and acknowledgment. Finally, the organization's vision should be clearly conveyed to all employees, as it gives their work purpose. With these elements in place, organizations set the stage for motivating people during difficult times by meeting their needs. Once these are satisfied, they are more likely to shift their focus towards new challenges.

Daniel Leidl (2009) points out that highlighting the historic importance of the organization's mission sets the stage for motivation. He states:

"Tying daily efforts into larger, global, and historical issues infuses the oftentimes monotonous work environment with a well-founded sense of importance and magnitude. Reminding employees that sidestepping the obstacles of today's markets is the stuff of history creates an engaging motivational narrative that frames a paycheck as more of a bonus than a single motivational carrot" (p. 1).

When employees believe that their efforts are serve a deeper purpose, they are more likely to produce. With goals and expectations set, along with plans of action for direction, members of a staff can directly channel their energy. "People want to achieve, want to be a part of success, and want a stake in the advancements with which they are associated," as stated in "Motivating employees through today's economic crisis - Executive strategies" (Leidl, 2009 , p. 2). Therefore, empowering employees could yield increased results. People will be more passionate about an opportunity when empowered to try.

Unfortunately, as Mimi Bacilek (2009) discusses in "Employee development in an economic crisis," many companies back off their employee development plans in an economic crisis. This, however, should be the time when growth opportunities are high. While competitors cut such strategies, training and educating employees can give one business a competitive advantage over another. Bacilek (2009) reports that " $33 \%$ of best-in-class organizations comprehensively address their employees and that employee engagement is the driving factor for success of these businesses" (p. 4). Therefore, human resource professionals should be equipped with the resources and authority to develop employees. Such educational efforts could even incorporate how to identify and help with stress-related issues due to the financial uproar.

In order for training and development efforts to occur, conversations regarding them must happen. Meeting time should be specifically set aside in order to discuss opportunities. Employees should also be given the chance to give feedback on what areas of development are concerns for them. From there employee development can be 
aligned with business goals. Having a strategic human resource focus is vital, especially in an unstable economy. An effective plan, as Bacilek (2009) explains, "maximizes the organization's resources, aligns employee development with business objectives and engages the energies of the workforce in the success of the business" ( $p$. 6). With clarity and focus, the human resources executive's role shifts to providing guidance and assistance and a mentor. Coaching then allows the executive to mentor leadership development and motivation across the organization, and the process becomes a long-term investment (Bacilek, 2009).

Aside from what aspects should be in place to foster motivation, there are others that organizations can look to avoid. As mentioned with job insecurity, many businesses will pretend that challenges do not exist. Most employees can sense tension in a work environment, meaning it is better to be honest in order to maintain trust. Cultivating distrust among employees can only lead to a decreasing morale and sense of loyalty. Thus, it is very important to keep communication open. Fears should be targeted in plans to address crucial concerns. Thus, meetings can become more frequent. Management should also make an effort to let employees have some say in decisions that affect them. And although fallbacks should be discussed, it is important to keep a positive outlook. It can be very discouraging when leaders display doubt in overcoming obstacles. Confidence can still be demonstrated with concern, and aids in keeping spirits high.

Herzberg (2003) mentioned that institutes can often become overbearing during times of uncertainty in order to appear strong. However, establishing a demanding atmosphere does not foster high levels of motivation. Instead, collaboration should be promoted, where communication from both parties is encouraged. People will need opportunities to talk, a natural aspect of dealing with this crises. Expressing concerns can help with daily tasks and improve long-term productivity. Employees should be encouraged to support one another. On the other hand, though empathy for employee concerns is sometimes appropriate, there must some sort of limit set on negative thinking among them. Management teams should listen to concerns, but then encourage employees to develop strategies for making the best of difficult situations.

\section{CONCLUSION}

Preserving a positive organizational climate is important in a time when layoffs and unemployment are high. Growing uncertainties directly affect commitment and organizational success. Implementing practices that get employees engaged is a must in order for businesses to survive. Strategies should be connected to the company's vision and mission. Organizations should strive to establish such an unwavering approach to employee motivation and retention so that even an unstable market couldn't call for a complete transformation. However, strategies under uncertainty must sometimes be adopted. In order to adapt in an economic crisis, first realization for change needs to occur. From there, the mission, vision, and leadership can be redefined.

Job enrichment concerning motivation, however, should not be a one-time occasion. Instead, it should take continuous consideration from administration. When solid strategies are developed in a strong economy, organizations will remain strong in a weak one. Take for instance the companies now that still have very good financial standing. More than likely, they invested a great deal of time and effort into their organizational development to plan for tough times.

Problems in an uncertain economy can make way for new opportunities. Crisis is said to be the mother of invention. The current economic chaos will offer organizations opportunities to think innovatively about the future, and will allow for businesses to differentiate themselves from the competition. When adversity is overcome, satisfaction, reward, and motivation are sure to follow.

\section{AUTHOR INFORMATION}

Martin Carrigan is an Associate Professor of Law and Business at the University of Findlay, and the Director of Business Administration. He received his BA degree from the University of Notre Dame, his MBA from the University of Findlay, and his JD from the University of Toledo. 


\section{REFERENCES}

1. Bacilek, M. (2009, March). Employee development in an economic crisis. Human Resources IQ. Retrieved May 20, 2009 from http://www.humanresources iq.com/article.cfm?externalID=686

2. Blanchard, Scott, and David Witt. "Best Practices of Employee Motivation." Manufacturing-Today Winter 2009: 16-17.

3. Durbin, A.J. (2008). Human Relations for Career and Personal Success. Upper Saddle River, N.J.: Pearson Education, Inc.

4. $\quad$ Fitzgerald, Thomas H. "Why Motivation Theory Doesn't Work." Harvard Business Review July \& Aug. 1971: 37-44.

5. Gerstner, Louis V. Who Says Elephants Can't Dance? Leading a Great Enterprise through Dramatic Change. New York: Collins, 2003.

6. Gostick, Adrian, and Chester Elton. The 24-Carrot Manager. Layton: Gibbs Smith, 2002.

7. Greenhalgh, L. (1983). Managing the job insecurity crisis. Human Resource Management, 22(4), 431-444. Retrieved May 21, 2009, from Business Source Complete database.

8. Helzberg Jr., B. (2003, August). Motivating your sales force in a tough economy. American Salesman, 48(8), 11. Retrieved May 21, 2009, from Business Source Complete database.

9. Herzberg, F. (1987, September). One more time: How do you motivate employees? Harvard Business Review, 65(5), 109-120. Retrieved May 21, 2009, from Business Source Complete database.

10. Hinkin, Timothy R., and Chester A. Schrieshelm. "Performance Incentives for Tough Times." Harvard Business Review Mar. 2009: 26-26.

11. Jones, Stephen R. "Was There A Hawthorne Effect?" American Journal of Sociology 98 (1992): 451-68.

12. Leidl, D. (2009, February 19). Motivating employees through today's economic crisis - Executive strategies. Retrieved May 26, 2009, from http://ezinearticles.com/ ?Motivating-Employees-ThroughTodays-Economic-Crisis---Executive-Strategies\&id=2013731

13. Michelli, Joseph A. The Starbucks Experience. USA: McGraw-Hill Companies, 2007.

14. Motivating staff in a tough economy: Doctrine at Wal-Mart. (2003, April). Accounting Department Management Report, Retrieved May 21, 2009, from Business Source Complete database.

15. Nohria, N., Groysberg, B., \& Lee, L. (2008, October). Employee motivation: A powerful new model. Harvard Business Review, 86(10), 133-134. Retrieved May 21, 2009, from Business Source Complete database.

16. Tremayne, Jessica. "The Science of Service." Smart Business St. Louis Mar. 2009: 9-12.

17. Witt, Chris. "Rally Your Employees Through Words." Healthcare Executive May \& June 2009. 